\title{
A imagem escrita da infância
}

\author{
Márcia Arbex \\ Universidade Federal de Minas Gerais
}

A

o traçar seus primeiros desenhos, a criança transita entre a abstração e o grafismo, a figura e a caligrafia, mostrando-nos com clareza a afinidade entre o escritural e o pictural. Suas quase-letras estão próximas do ideograma, pois o que é traçado está entre a escrita e a pintura. Roland Barthes já afirmava que não há diferença entre literatura e pintura, uma vez que ambas vêm do mesmo corpo - a mão -, e argumenta que "na origem conjunta da escrita e da arte, houve o ritmo, o traçado regular, a pontuação pura de incisões insignificantes e repetidas. (...) O abstrato está na origem do grafismo, a escrita na origem da arte». ${ }^{1}$ Desde o século XIX, a rigidez da escrita alfabética começa a ser colocada à prova, revelando que a escrita ocidental não cortou inteiramente os laços com sua origem icônica. A partir de Mallarmé, a cultura alfabética foi tomada pela imagem e tanto a literatura quanto as artes visuais testemunharam do surgimento de inúmeros exemplos que evidenciam a iconicidade da escrita, a reintegração da visualidade e da espacialidade da escrita na poesia, na ilustração, nos cartazes, nos jogos literários com a letra, nos jogos dos pintores com as palavras e dos poetas com a imagem. ${ }^{2}$

\footnotetext{
${ }^{1}$ BARTHES, 2000, p.75. [Tradução da Autora].

${ }^{2}$ Cf. CHRISTIN, 2001.
} 


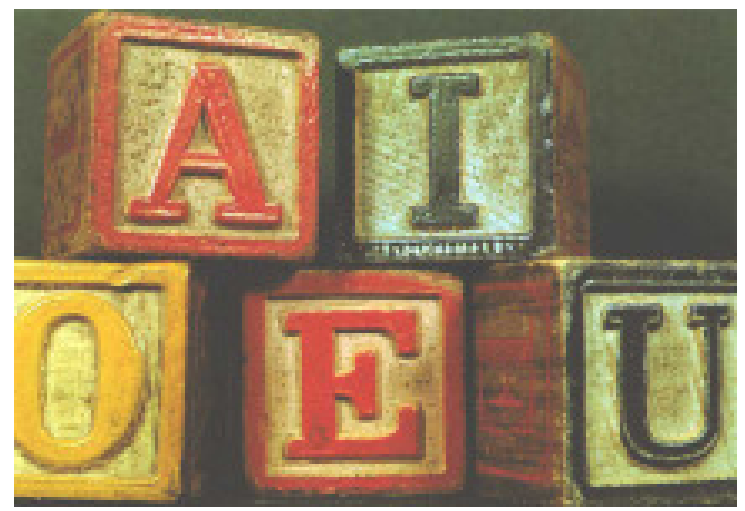

Arthur Rimbaud surge naturalmente como nosso guia, eleito para nos conduzir em seu bateau ivre através do diálogo entre a escrita e a imagem, em sua relação com a infância:

"Admirava as pinturas medíocres, bandeiras de portas, cenários, telões de saltimbancos, letreiros, iluminuras populares; a literatura ultrapassada, latim de igreja, livros eróticos mal escritos, romances dos tempos da avó, contos de fadas, almanaques infantis, velhas óperas, refrões simplórios, ritmos singelos.

Sonhava com cruzadas, viagens de descobertas cujos relatos não existem, repúblicas sem história, guerras de religião reprimidas, revoluções de costumes, deslocamentos de raças e de continentes: acreditava em todas as encantações.

Inventei a cor das vogais! (...). ${ }^{3}$

Apenas em algumas linhas o poeta iluminado reúne todo o imaginário infantil que servirá de ponto de partida para muitos poetas, escritores e artistas, aqueles que buscaram resgatar a cor das vogais, aproximar o texto e a imagem, características dos almanaques infantis, dos letreiros, das iluminuras populares, dos contos de fadas e relatos de viagens extraordinárias à maneira de Alice no país das maravilhas (1865) ou Vinte mil léguas submarinas (1869).

A relação da imagem - sobretudo a fotográfica - com o texto, nos autores escolhidos para essa travessia da imagem escrita da infância, ora se

${ }^{3}$ RIMBAUD, 1983, p.90. 
apresenta em um suporte comum, livro ou álbum, caracterizando uma relação intratextual, entendida como uma "ilustração" não-hierarquizada entre os dois sistemas ; ora o texto incorpora a imagem ou o imaginário da infância, através de citações diretas e indiretas. Em ambos os casos a imagem constitui-se como geradora da obra e o diálogo se opera no imaginário.

\section{A imagem geradora de textos de ficção: Duras, Tournier, Barthes}

La mer écrite[O mar escrito] é o título de um pequeno álbum composto de textos e de fotografias, os primeiros de autoria de Marguerite Duras, as fotos de Hélène Bamberger. Resultado do trabalho realizado em Trouville durante o verão de 1980, quando as autoras costumavam passear todas às tardes pela cidade e pela praia, enquanto Hélène tirava fotografias. Um dia, Maguerite começou a dizer o quê fotografar, manifestou exigências cada vez mais precisas e o trabalho a quatro mãos foi tomando forma, tornandose um verdadeiro trabalho de colaboração.

Das trinta e uma fotografias publicadas, apenas uma retrata uma criança: um menino cercado de adultos - presença humana absoluta no livro. O texto, sempre à esquerda, diz: "a criança da fotografia não estava contente e a trouxemos para a foto com a luz do sol; em seguida a criança se tornou bela e só. Mantivemos tudo. Algumas vezes as crianças a abraçam, deixamos que abracem as imagens. ${ }^{4}$

Isolada do grupo de mulheres distraídas por alguns instantes, atraído pela maquete de barco que sonha talvez um dia conduzir com seu boné de marinheiro, quando conseguir se livrar da camisa de colarinho..., a criança olha fixamente a câmera. A foto capta o momento em que a contrariedade do menino começa a abrir espaço para a aceitação, para o "abraço da foto", consentindo em tornar-se imagem.

${ }^{4}$ DURAS, 1996, p. 56. [T.A.] 

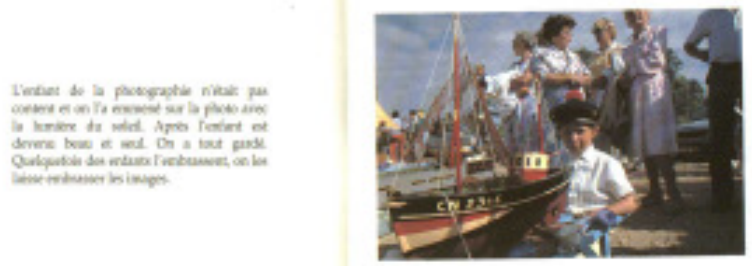

Neste álbum, o texto à esquerda e a fotografia, à direita, ocupam o centro das páginas respectivas, não ultrapassando os limites invisíveis da mancha gráfica. Não há primazia de um sobre o outro, ambos são apresentados simultaneamente e transformam as relações entre a palavra e a imagem, antes hierarquizadas na ilustração. A fotografia não ilustra o texto, o texto não é o comentário da imagem: eles se completam.

A foto da página anterior parece prenunciar a que acabamos de citar : trata-se de uma vista da praia de Trouville, com suas cabines típicas da Normandia, pessoas caminhando ao longe e, em primeiro plano, um largo círculo sobre a areia, formado pelos objetos ali deixados, de maneira ao mesmo tempo lúdica e organizada. Olhando com mais atenção um detalhe do círculo, identificamos uma mulher brincando com uma criança, agachadas na areia. O texto conota a fotografia, direciona sua leitura ao evocar as colônias de férias: "há sempre uma criança que quer seguir o mar, para ver". 5

O menino da fotografia, por seu ar contrariado e, talvez, pelo caráter homofônico da palavra mer do título do livro, nos remete à personagem Anne, de Moderato Cantabile (1958). Desde as primeras páginas, no episódio da aula de piano, deparamo-nos com essa mãe completamente "sem defesa diante de seu filho", ${ }^{6}$ que encara sua existência com espanto e perplexidade: "às vezes acho que te inventei, que isso não é verdade", 7 como se tratasse,

\footnotetext{
${ }^{5}$ DURAS, 1996, p.54-55. [T.A.]

${ }^{6}$ DURAS, 1958, p.132. [T.A.]

7 DURAS, 1958, p.46. [T.A.]
} 
justamente, de uma personagem de ficção. E que para se justificar junto à professora de piano extenuada pelos caprichos do menino que a contraria, a mãe diz, rindo: "eles não pediram para viver (...) e ainda por cima queremos que aprendam piano, o quê a senhora esperava"! Talvez seja o filho de Anne, conduzido todos os dias pela beira-mar até à cidade, testemunho inocente de seus encontros com Chauvin, ansioso por um barco vermelho a motor, talvez seja ele que Duras reviu no menino da fotografia de La merécrite.

Contrariamente a Marguerite Duras, que não faz da infância o tema central de sua obra, Michel Tournier é um escritor apaixonado pela fotografia e pelo mundo da infância. Através do diálogo intertextual, Michel Tournier reanima e atualiza contos, mitos e estórias como a do Pequeno Polegar, Papai

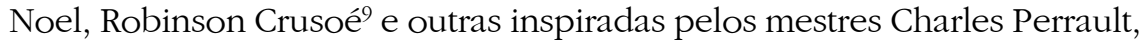
La Fontaine, Jack London ou Saint-Exupéry.

A fotografia em geral, e sobretudo a de crianças, adquire um valor especial para o autor de Le Coq de bruyère. Porquê fotografar crianças? Tournier diz que a razão está no fato de desejarmos fixar seu aspecto efêmero. Mas uma segunda razão acrescenta-se à primeira: "se pudessemos comer as crianças, nós as fotografiaríamos menos. Por sua pequenez e frescor, a criança suscita vocações antropófogas, até mesmo sádicas.. ${ }^{10} \mathrm{Tal}$ qual o ogro dos contos de fadas, o fotógrafo seria uma espécie de bicho papão, e a fotografia assumiria uma função "devoradora", "antropofágica".

Como um pequeno museu individual, o álbum Des Clefs et des serrures: images et proses [Chaves e fechaduras: imagens e prosas] (1979) reúne textos de Tournier e imagens de diversos fotógrafos, entre eles HenriCartier Bresson, Robert Doisneau, Edouard Boubat, Jacques-Henri Lartigue e Lewis Caroll. Às vezes o "texto se inspira diretamente de uma fotografia da qual se torna, então, 'legenda', ou seja, ao mesmo tempo o comentário minucioso e a exaltação fabulosa". Às vezes a fotografia funciona como contraponto distante ao texto, ampliando-o, enriquecendo-o.

\footnotetext{
${ }^{8}$ DURAS, 1958, p.94. [T.A.]

${ }^{9}$ Cf. os romances Vendredi ou les limbes du Pacifique e sua versão para crianças, Vendredi ou la vie sauvage, que retoma a estória de Robinson Crusoé.

${ }^{10}$ Magazine littéraire, n. 226, janvier 1986, p.13. [T.A.]
} 
Nesse diálogo do escritor com a imagem, a fotografia é considerada como «um motor, como uma musa do pensamento ou ainda (...) um espelho das obsessões" ${ }^{11}$ diz Tournier, contribuindo assim para a noção de imagem geradora do texto de ficção: "gerado pela imagem, o texto (de ficção) não fala sobre/a respeito da imagem. Ele fala a partir de, logo, à distância da imagem. E é desse e nesse distanciamento que ele se constitui como tal e encontra sua justificação." ${ }^{12}$

No texto intitulado «Tocar", Tournier evoca uma lembrança de quando tinha seis anos: a paixão sofredora por uma pantera negra do zoológico do Jardin des Plantes que o levava à suplicar para deixarem com que ficasse perto dela, a tocasse, a acariciasse, como o personagem Mogli o faz no Livro da Selva, de Rudyard Kipling.

A advertência mil vezes repetida: Não toque! torna a criança, segundo Tournier, «um cego, um cão sem faro, vagando tristemente num mundo onde tudo é fechado dentro de vitrines", uma vez que nossa sociedade "higiênica e puritana mostra-se cada vez menos favorável ao conhecimento e às satisfações táteis." Pedir a uma criança que "toque apenas com os olhos", seria uma atitude tirânica que impediria qualquer impulso infantil, qualquer contato erótico, favorecendo ao contrário uma "inflação galopante de imagens". ${ }^{13}$
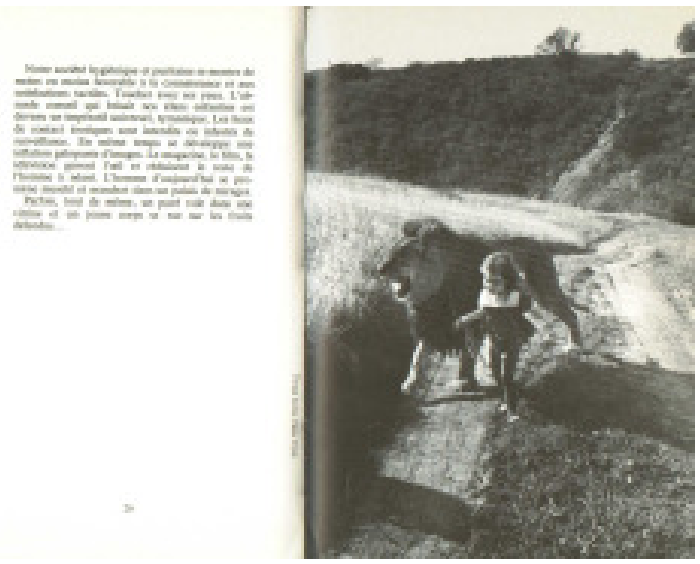

${ }^{11}$ Magazine littéraire, n. 226, janvier 1986, p.17. [T.A.]

12 MONCOND'HUY \& MOURIER-CASILE, 1996, p.4. [T.A.]

13 TOURNIER, 1979, p.25-26. 
A fotografia que acompanha o texto (cujo autor não é identificado) é o contraponto dessa contastação: uma menina de sapatinhos brancos puxando pela corrente um leão, concretiza, em imagem, o desejo reprimido do autor em relação à sua pantera negra, o tabu do toque. Mostra, ao mesmo tempo, uma imagem inédita, inacreditável par muitos, por reunir o símbolo da selvageria e o da infância feliz, o cúmulo da força dominado pela fragilidade da criança, agora no comando, mas em perfeita comunhão com seu animal de estimação, seu cãozinho. Imagem quase surrealista ao registrar o improvável, concretizando desejos, "espelhando obsessões", colocando em dúvida o "estar lá da coisa", como observa Barthes em A Câmara clara.

Do tocar, Tournier passa ao olhar, com o texto "A imagem erótica", o qual vem acompanhado de uma célebre fotografia de Lewis Carroll. Dentre as possibilidades de expansão do erotismo, definido desde as primeiras linhas como "o exercício da sexualidade considerada como um fim em si, como puro luxo", ${ }^{14}$ Tournier destaca o lugar privilegiado ocupado pela fotografia, em comparação com a pintura ou a escultura. Com a fotografia, a distância entre o modelo e o espectador diminuiu consideravelmente; possuir a imagem da pesssoa desejada é uma grande satisfação, diz Tournier, mas ser o fotógrafo do corpo desejado é ainda melhor.

Nesse sentido, Lewis Carroll, aliás, o pastor Charles Lutwidge Dodgson (1832-1898) é considerado um dos primeiros a ter descoberto as possibilidades eróticas da fotografia. Autor de inúmeros clichés de meninas em poses lânguidas, vestidas à moda grega, turca, chinesa ou romana, ou então fantasiadas de pequenas mendigas em farrapos, o autor de Alice no país das maravilhas teria praticado, na visão de Tournier, uma forma de erotismo da mais alta espécie, o erotismo-amor, paixão, ternura, em que "toda a vida de um homem de gênio se engaja e se cristaliza em uma obra sublimen. ${ }^{15}$

Onirismo, erotismo, memória. O poder da fotografia de revelar "uma certa persistência da espécie" ${ }^{16}$ como diz Barthes, encontra-se na imagem do novaiorquino Arthur Trees, a qual dialoga com o texto "A imagem abismada".

\footnotetext{
${ }_{14}$ TOURNIER, 1979, p.103. [T.A.]

15 TOURNIER, 1979, p.108. [T.A.]

16 BARTHES, 1984, p.154.
} 


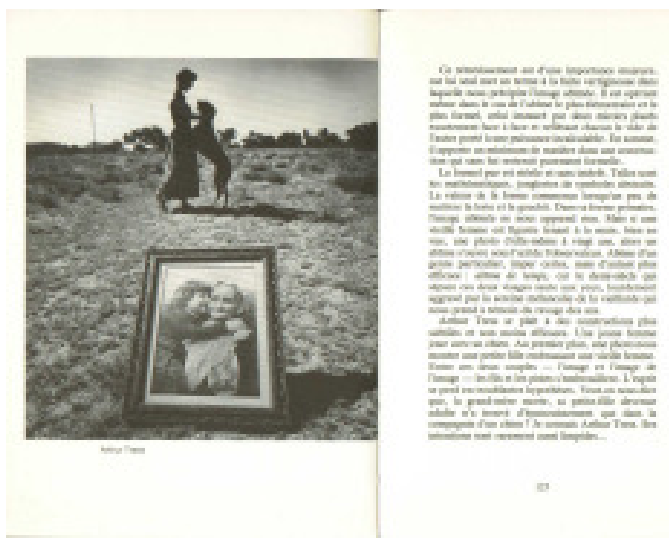

A imagem serve de ponto de partida para uma reflexão sobre o caráter especular da noção de mise en abyme à qual se superpõe a noção de imagem desgastada pelo tempo, a de abîme du temps. O evidente abismo do tempo que separa o rosto da criança e o da senhora, ali reunidos carinhosamente pela moldura, está inserido na imagem como se um vazio tivesse se formado, um espaço aberto no tempo, trazendo para o presente da jovem com o cão uma imagem de "serena melancolia ${ }^{17}$. Como uma natureza morta, a imagem nos chama a testemunhar da fugacidade do tempo: leio (como Barthes a respeito da foto de sua mãe): "Isso será e isso foi", a fotografia diz a morte no futuro. ${ }^{18}$

Em contraponto ao universo de Arthur Tress, a fotografia de Edouard Boubat evoca a ternura da infância, a predileção pelo tema da maternidade, tratado sempre de modo espontâneo, leve, angelical. O texto gerado a partir da imagem da menina com seu vestido novo, com seu olhar voltado para o alto, para frente, da origem a um dos textos mais íntimos e poéticos de Michel Tournier, intitulado "Um dia, uma mulher", por evocar uma infância sonhada ao lado pai, que guiará sua filha durante seus primeiros anos de vida, "ensinando-lhe a se aproximar sem medo das flores, dos animais e dos homens", acolhendo-a em seus braços "como em uma gruta", deixando-a escalar suas costas "como se fosse uma ilha" ${ }^{19}$

\footnotetext{
${ }^{17}$ TOURNIER, 1979, p.121. [T.A.]

${ }_{18}$ BARTHES, 1984, p.142.

19 TOURNIER, 1979, p.189. [T.A.]
} 
Se por um lado a fotografia de uma criança pode gerar um texto que projeta seu autor para o futuro, por outro lado a imagem poderá, ao contrário, permitir o remontar do tempo: “(...) contemplando uma foto em que [minha mãe] me estreita, criança, junto dela, posso despertar em mim a doçura enrugada do crepe da China e o perfume do pó-de arroz.», ${ }^{20}$ diz Roland Barthes.

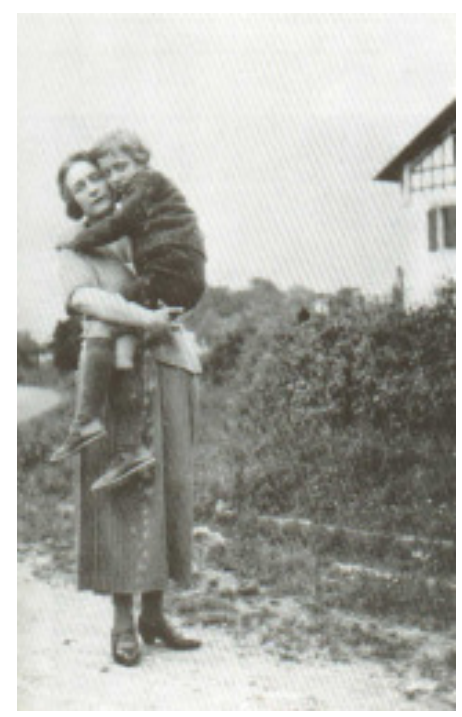

Todo o "imaginário de imagens" da infância suscita em Barthes "um tipo de sonho obtuso cujas unidades são os dentes, os cabelos, um nariz, uma magreza, pernas com longos braços que não me pertencem, sem todavia pertencerem a outra pessoa a não ser eu mesmo". Na imagem da criança que ele fora um dia, o autor descobre ainda o irredutível, o avesso obscuro dele mesmo, o seu tédio, sua vulnerabilidade, seus desesperos. Portanto, não é a nostalgia de um tempo feliz que o encanta nessa fotografias, mas algo de mais perturbador, uma «inquietante familiaridaden: ${ }^{21}$ «a Fotografia (...), diz Barthes, representa esse momento sutil em que, para

\footnotetext{
${ }^{20}$ BARTHES, 1984, p.98.

${ }^{21}$ BARTHES, 1995, p.8. [T.A.]
} 
dizer a verdade, não sou nem um sujeito nem um objeto, mas antes um sujeito que se sente tornar-se objeto: vivo então uma microexperiência da morte (...): torno-me verdadeiramente espectro. ${ }^{22}$

No início do livro Roland Barthes par Roland Barthes, o autor adverte o leitor que aquilo que ele vai ler/ver deve ser considerado como dito por uma personagem de romance. Assim como Barthes, os artistas plásticos Christian Boltanski e Jean Le Gac caracterizam-se também como personagens de ficção, abusando de fotografias para "remontar o tempo" e para reconstituir sua infância.

\section{A imagem na construção da autoficção: Christian Boltanski e Jean Le Gac}

A partir de materiais pouco substânciais, efêmeros, frágeis ou inusitados, como jornais, roupas e objetos usados, sombras e fantoches, fotografias que um dia foram descartadas, Christian Boltanski produz uma obra na qual o tema da infância e a utilização da fotografia são essenciais.

Para Boltanski, a imagem da infância é amplamente utilizada na construção de uma "versão mitologizada" da sua própria infância, de uma autoficção. Diz Boltanski: "uma grande parte da minha atividade tem a ver com a idéia de biografia, mas uma biografia totalmente falsa e que é apresentada como falsa, com todo tipo de falsa evidencia. (...) quanto mais as pessoas falarem de CB, menos ele existirán. ${ }^{23}$ Nessa perspectiva, as fotografias interessam-lhe pelo fato de serem "percebidas como verdadeiras, como uma prova de que o evento retratado é real"; elas criam a ilusão da realidade e nessa ilusão reside seu lado obscuro: ao captar um momento da vida a foto torna-se, ao mesmo tempo, o espectro da morte.

Boltanski, artista plástico, faz livros cujo objetivo é a "busca arqueólogica nas profundezas de minha memória", como ele diz. ${ }^{24}$ Os próprios títulos já indicam a natureza das narrativas visuais: Recherche et présentation de tout ce qui reste de mon enfance, 1944-1950 [Busca e

\footnotetext{
22 BARTHES, 1984, p.27.

${ }^{23}$ Apud GUMPERT, 1994, p.12. [T.A.]

${ }^{24}$ Apud GUMPERT, 1994, p.23. [T.A.]
} 
apresentação de tudo que resta de minha infância, 1944-1950] (1969), Essais de reconstituition d'objets ayant appartenu à CB entre 1948 et 1954 [Ensaios de reconstituição de objetos que pertenceram a CB entre 1948 e 1954] (1969), Reconstituition des gestes effectués par CB entre 1948 et 1954 [Reconstituição dos gestos efetuados por CB entre 1948 et 1954] (1970). Nessas publicações, Boltanski reúne fotos de família, fotos de escola, retratos da infância, do quarto, da camisa usada, páginas de caderno escolar, brinquedos, utensílios, entre outros documentos e objetos que se revelaram falsos e não os objetos originais do artista, nem as memórias que dizem ser, indicando claramente o projeto de autoficção em curso. Tal projeto associando sempre imagem e texto continua em outros trabalhos:

Em Les Saynètes comiques [Esquetes cômicos], de 1974, Boltanski se veste com um terno demasiado pequeno para ele, a cabeça coberta pelo paletó, e fotografa a si mesmo encenando episódios de sua infância, como a morte do avô ou uma terrível descoberta na praia, cada imagem acompanhada de uma legenda.
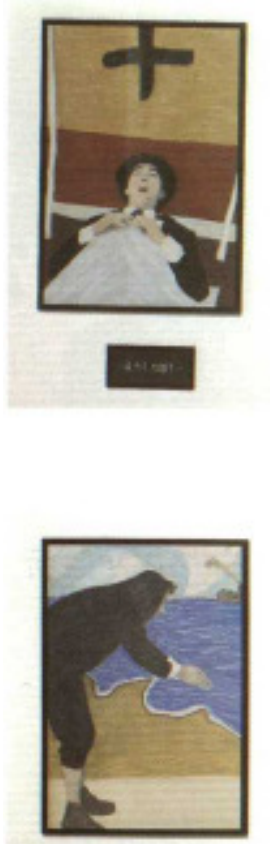

5-cromed
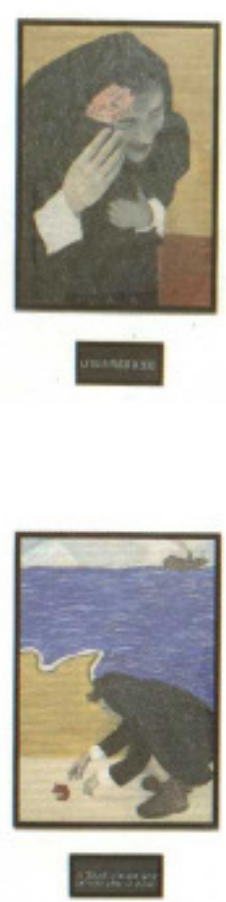
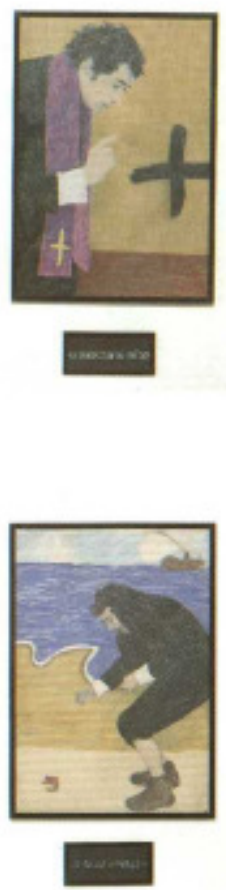
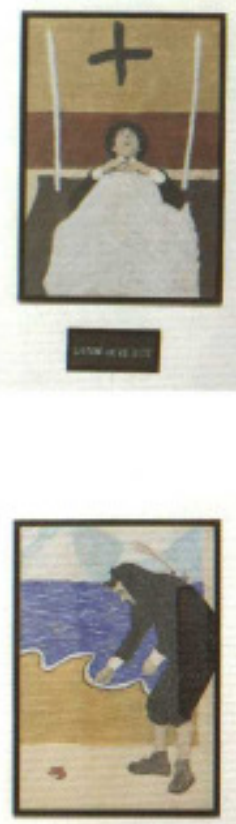

ancer 
Em 10 Portraits photographiques de CB 1946-1964[10 Retratos fotográficos de CB 1946-1964], vemos supostos retratos do artista em diversas idades, de 2 anos a 18 anos, fotografados no mesmo local e na mesma pose.

A fotografia de crianças integra ainda trabalhos de caráter menos autobiográfico e menos lúdico: Les 62 membres du Club Mickey en 1955 (1972) [Os 62 membros do Clube Mickey em 1955], que reúne fotos anônimas publicadas inicialmente na revista infantil Clube Mickey Mouse, ${ }^{25}$ e Portraits des élèves du C.E.S. des Lentillères en 1973 [Retratos dos alunos do colégio de Lentillères en 1973], que agrupa as fotos preferidas dos alunos do referido colégio.

Podemos considerar que a tentativa de apropriação de uma infância "normal, burguesa", enquadrada, como foi a do próprio artista, revela-se finalmente deceptiva. As fotografias coloridas, deslocadas e dramatizadas pela iluminação crua, sinalizam, no caso do Clube Mickey, que tais crianças não existem mais; e no caso das fotos de escola, o grande mural constitui um verdadeiro ex-voto.

Nota-se, sobretudo, nestas últimas, a utilização de um flash bastante forte que causa uma impressão de congelamento das imagens das crianças em poses rígidas. A imobilidade da foto é, de acordo com Barthes, ${ }^{26} \mathrm{como}$ o resultado de uma confusão perversa entre dois conceitos: o Real e o Vivo. Ao atestar que o objeto foi real, a fotografia induz a pensar que ele está vivo (...); mas ao deportar esse real para o passado («isso foi"), ela sugere que ele já desapareceu.

Esse congelamento da imagem no tempo e no espaço, sinaliza ainda um trabalho em torno da noção de cliché, de lugar-comum e de gosto que se desenvolverá mais claramente em Images Modèles [Imagens modelos] e Les Jolis enfants [As lindas crianças], ambos de 1975. Para este, Boltanski partiu de fotos já existentes que parecem ter sido tiradas para as publicidades de sabonete, de leite ou outro produto infantil. São crianças saudáveis, risonhas, rosadas, acompanhadas de seu bichinho de pelúcia ou brinquedo preferido, "detalhes que constituem o próprio material do saber etnológico" ${ }^{27}$ sob um

\footnotetext{
${ }_{25}$ Revista que o artista diz ter guardado desde a idade de 11 anos, cujas imagens foram refotografadas em preto e branco e apresentadas em séries verticais.

${ }^{26}$ BARTHES, 1984, p. 118.

${ }^{27}$ BARTHES, 1984, p. 49.
} 
fundo colorido de estúdio. Selecionadas, ampliadas e dispostas lado a lado, em série, formam uma paródia dos clichés de inocência e felicidade associadas à imagem da criança.

A ambigüidade da fotografia com sua função de preservação da memória de algo que já não existe, sobre um suporte efêmero, perecível, fica ainda mais evidente na série Les Monuments, de 1986. A imagem que serviu de estímulo gerador, neste caso, é uma foto da turma da escola de 1951 a que pertenceu o artista: ${ }^{28}$
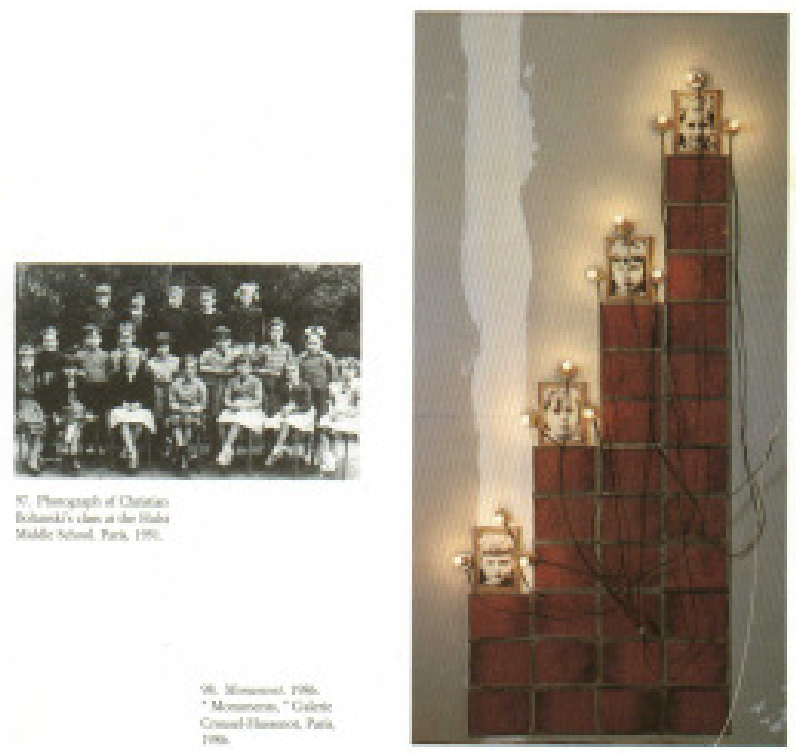

As instalações para os monumentos foram realizadas com pequenas fotos em preto e branco, extraídas da foto de classe, acrescidas de molduras feitas com papéis de presente brilhantes ou metálicos, como aqueles usados

28 "Todas essas crianças, incluindo eu mesmo, não me lembro de nenhum de seus nomes, lembro-me apenas dos rostos na foto. Pode-se dizer que elas desapareceram de minha memoria, que esse periodo da vida esta morto. (...) é porque senti que precisava prestar homenagem a esses "mortos", os quais, nesta imagem, todos parecem mais ou menos como cadaveres.». Boltanski apud GUMPERT, 1994, p.83. [T.A.] 
nos embrulhos dos presentes de Natal. Organizadas em formas geométricas, piramidais, as fotos foram iluminadas por pequenas lâmpadas cujos fios elétricos atravessam desordenadamente a superfície, rompendo com a simetria da construção, o conjunto apresentado na escuridão.

Na série Monuments: Les enfants de dijon [Monumentos : as crianças de Dijon], de 1985, Boltanski reutilizou as mesmas fotos das crianças do colégio Lentillères, desta vez coloridas e ampliadas, fora de foco, dispersas nas paredes e iluminadas individualmente. Evocação de monumentos funerários ou memoriais públicos, de ícones bizantinos ou ex-votos (mais uma vez), as lâmpadas provocam um efeito de velas acesas em movimento de devoção a esses figurantes anônimos no drama do próprio Boltanki - a alusão aos campos de concentração e à origem judaica do artista tornam-se mais evidentes; ressaltam a conotação religiosa e sagrada que o trabalho vem adquirindo com a utilização mais dramática do espaço, da encenação da fotos em espaços mais amplos, que conferem à exposição um caráter teatral.

Trabalhando com noções próximas às de Boltanski, o francês Jean Le Gac também produz uma obra composta de fotos e textos: uma obra fictícia que coloca em cena um pintor imaginário. Suas fotografias remetem aos textos que, por sua vez, remetem às imagens, numa mise en abyme permanente. Impregnado de literatura popular, Jean Le Gac se comporta como um detetive do cotidiano atento aos ínfimos detalhes, aos menores gestos. Ele simula uma vida de artista, vive como em um romance de aventuras, citando frases retiradas de livros infanto-juvenis. Mistério, peripécias, suspense, todos os ingredientes da literatura popular, tal como amava Rimbaud, aí se encontram.

Se a figura da criança está menos presente nos trabalhos de Le Gac do que nos de seu contemporâneo Boltanski, isso não significa que o imaginário infantil esteja ausente. Pelo contrário. Subjugado pelas imagens, o artista busca nos livros ilustrados e nos romances de aventura o material de base para suas narrativas autoficcionais: em Le Peintre, exposition romancée [O pintor, exposição romanceada] (1978), o artista conta a história de um professor de desenho: suas origens, sua vocação, sua caixa de tintas, sua férias, as anedotas que permitem retraçar sua vida de artista. 


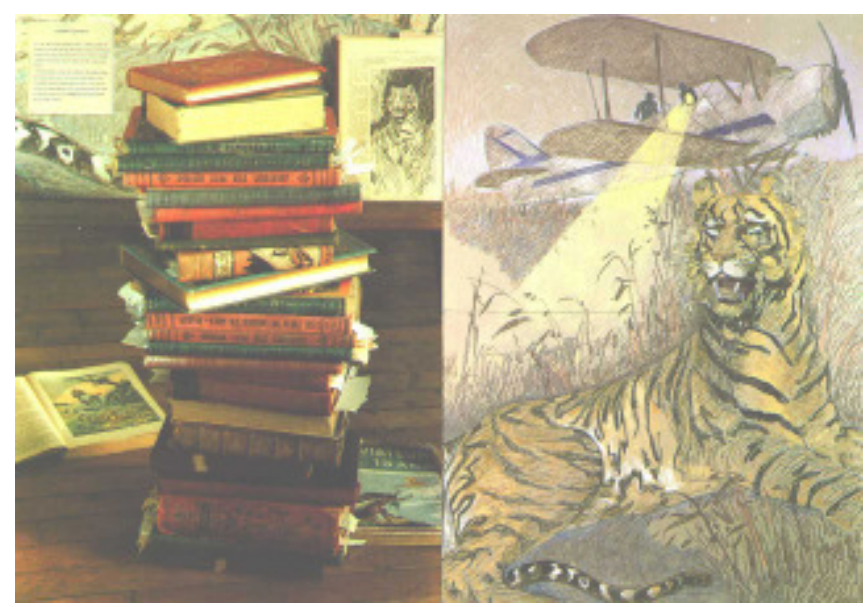

Copiando, o artista continua sua empresa de resgate de antigas imagens que estão na origem de sua vocação: a capa do livro das Aventuras de um pequeno Buffalo, de Arnould Galopin, serve de material para o episódio do rapto da criança, na narrativa de O Professor de desenho (1975). Vários volumes do mesmo livro de aventuras aparecem, assim como os exemplares de Tour du monde en sous-marin, Le Chasseur de Fauves e Aviateur à 15 ans, em um dos quadros da série Le délassement d'un peintre parisien (1985), espécie de díptico que apresenta, à direita, a imagem de um tigre, ampliação da ilustração de um dos romances de aventura.

A fotografia, para Boltanki e Le Gac, é o veículo para captar a efemeridade da vida e o tema da infância é o meio de traduzir uma ausência. Através da autoficção, não é apenas a infância do artista que é buscada, reconstituída, mas a infância de certa geração, em um certo contexto, envolvendo a noção de uma memória coletiva.

O breve percurso aqui proposto através da obra de escritores e artistas que utilizam a palavra e a imagem simultaneamente, vem confirmar a tendência à abolição das fronteiras entre o legível e o visível na literatura e nas artes contemporâneas, cuja origem encontra-se na própria iconicidade da escrita, nas afinidades entre a letra e a imagem: traço e ritmo. A fotografia, ao indicar as fronteiras tênues entre ilusão e realidade, apresenta-se como suporte privilegiado para traduzir o "mito da infância admirável": infância cujo dom seria unir o real e o imaginário, como diziam os surrealistas. Para finalizar esse percurso, evocarei a imagem do poeta que abriu essa reflexão: 
o célebre retrato de Rimbaud aos dezesseis anos, revelado pela câmera de Carjat; o poeta que, nas palavras de André Breton, é o verdadeiro deus da puberdade, aquele que faltava, justamente, a todas as mitologias. ${ }^{29}$

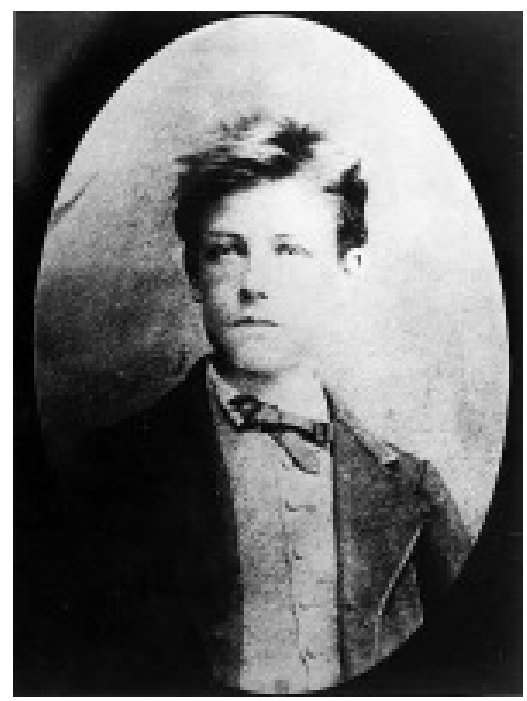

\section{Referências Bibliográficas}

BARTHES, Roland. A câmara clara: nota sobre a fotografia. Trad. Julio Castañon Guoimarães. Rio de Janeiro: Nova Fronteira, 1984.

BARTHES, Roland. O Obvio e o obtuso: ensaios críticos III. Trad. Léa Novaes. Rio de Janeiro: Nova Fronteira, 1990.

BARTHES, Roland. Le Plaisir du texte précédé de Variations sur l'écriture. Paris: Editions du Seuil, 2000.

BRETON, André. Anthologie de l'humour noir. Oeuvres complètes. Paris: Gallimard, 1988. (Bibliohèque de la Pléiade).

${ }^{29}$ BRETON, 1988, p.212. 
Catalogue Jean Gac. Exposition du 6 janvier au 7 février 1990. Paris: Galerie Daniel Templon.

CHRISTIN, Anne-Marie. L'Image écrite ou la déraison graphique. Paris: Flammarion, 2001.

DURAS, Marguerite. La Mer écrite. s/1: Marval, 1996.

DURAS, Marguerite. Moderato Cantabile. Paris: Les Editions de Minuit, 1958.

GUMPERT, Lynn. Christian Boltanski. Paris: Flammarion, 1994.

Magazine littéraire, n.226, janvier 1986.

MONCOND'HUY, Dominique, MOURIER-CASILE, Pascaline. L'Image génératrice de textes de fiction. Poitiers, La Licorne, 1996.

RIMBAUD, Arthur. Une saison en enfer/Uma estadia no inferno. Tradução de Ivo Barroso. Rio de Janeiro: Civilização Brasileira, 1983.

Roland Barthes par Roland Barthes. Paris: Editions du Seuil, 1995. (Ecrivains de toujours).

TOURNIER, Michel. Des Clefs et des serrures: images et prose. Paris : Editions du Chêne, 1979.

\section{Resumo}

Reflexão sobre algumas modalidades da inscrição da imagem da infância na produção artistico-literária contemporânea, em especial em obras que se caracterizam pelo diálogo entre o texto e imagem, seja ela geradora do texto de ficção, seja como material para reconstituição de uma autoficção.

\section{Résumé}

Réflexion sur quelques modalités d'inscription de l'image de l'enfance dans la production artistique littéraire contemporaine, en particulier dans les travaux qui se caractérisent par un dialogue entre le texte et l'image, qu'elle soit génératrice du texte de fiction, soit comme matériel pour la reconstitution d'une autofiction. 